\title{
New records of moths (Lepidoptera) from Novaya Zemlya, Arctic Russia, with a supplement of DNA barcoding data
}

\author{
Новые находки чешуекрылых (Lepidoptera) с архипелага \\ Новая Земля с данными АНК-баркодинга
}

\author{
Vitaly M. Spitsyn", Alexander V. Kondakov, Alena A. Tomilova, \\ Elizaveta A. Spitsyna, Grigory S. Potapov \\ B.М. Спиџын, А.В. Кондаков, А.А. Томилова, Е.А. Спиџына, \\ Г.С. Потапов
}

\footnotetext{
N. Laverov Federal Center for Integrated Arctic Research of the Ural Branch of the Russian Academy of Sciences, Northern Dvina Emb. 23, Arkhangelsk 163000, Russia.

Федеральный исследовательский центр комплексного изучения Арктики имени академика Н.П. Лаверова Уральского отделения Российской академии наук, набережная Северной Двины, 23, Архангельск 163000, Россия.

* Corresponding author: spitsyn.v.m.91993@yandex.ru
}

KEY WORDS: biogeography, Arctic islands, Barents Sea region, Crambidae, Geometridae.

КЛЮЧЕВЫЕ СЛОВА: биогеография, арктические острова, Баренцево море, Crambidae, Geometridae.

ABSTRACT. This paper reports the first records of four moth species from Novaya Zemlya: Eupithecia gelidata, Rheumaptera subhastata, Entephria byssata (Geometridae), and Udea cf. cacuminicola (Crambidae). The COI barcode data is provided for each species. Molecular sequences suggest that the Lepidoptera fauna of Novaya Zemlya was originated recently via longdistance dispersal of widespread lineages from the mainland.

РЕЗЮМЕ. Приводятся первые находки четырех видов чешуекрылых на архипелаге Новая Земля: Eupithecia gelidata, Rheumaptera subhastata, Entephria byssata (Geometridae) и Udea cf. cacuminicola (Crambidae). Для каждого вида приводятся последовательности нуклеотидов гена COI, на основе которых можно предположить, что фауна чешуекрылых архипелага возникла недавно.

\section{Introduction}

Novaya Zemlya is one of the most inaccessible archipelagoes of the High Arctic [Potapov et al., 2018]. As a result, its fauna remains poorly known. The Lepidoptera fauna of Novaya Zemlya includes 30 species [Jacobson, 1898; Rebel, 1923; Karsholt et al., 2013; Kullberg et al., 2018], while the actual species richness seems to be at least twice this value. For example, only two geometer species (Geometridae) are known from Novaya Zemlya
[Kullberg et al., 2018], whereas 4-5 species are recorded from neighboring areas, i.e. Yugorsky Peninsula and Kolguev Island [Kullberg et al., 2013, 2018].

In this paper, we present the first records of four moth species from Novaya Zemlya and discuss the putative origin of this insular fauna by means of a molecular approach.

\section{Material and Methods}

Moths were collected with an entomological net near the Bezymyannaya Bay (Novaya Zemlya, Yuzhny Island) from July 19 to July 26, 2017. Specimens were prepared using standard methods [Schauff, 2001]. They are deposited in the Russian Museum of Biodiversity Hotspots (RMBH), N. Laverov Federal Center for Integrated Arctic Research of the Ural Branch of the Russian Academy of Sciences (Arkhangelsk, Russia).

Total DNA was extracted from a single leg of each dry specimen according to standard phenol/chloroform procedures [Sambrook et al., 1989]. The mitochondrial cytochrome c oxidase subunit I (COI) gene was amplified and sequenced using primers LCO1490 [Folmer et al., 1994] and LepR [Hajibabaei et al., 2006]. The PCR mix contained approximately $200 \mathrm{ng}$ of total cell DNA, 10 pmol of each primer, 200 ìmol of each dNTP, 2.5 il of PCR buffer (with $20 \mathrm{mmol} \mathrm{MgCl}_{2}$ ), 0.8 units Taq DNA polymerase (SibEnzyme Ltd., Russia), and $\mathrm{H}_{2} \mathrm{O}$ was added for a final volume of 25 il. Temperature cycling

How to cite this article: Spitsyn V.M., Kondakov A.V., Tomilova A.A., Spitsyna E.A., Potapov G.S. 2021. New records of moths (Lepidoptera) from Novaya Zemlya, Arctic Russia, with a supplement of DNA barcoding data // Russian Entomol. J. Vol.30. No.2. P.178-181. doi: 10.15298/rusentj.30.2.12 
was as follows: $95^{\circ} \mathrm{C}$ (5 min), $30-33$ cycles of $95^{\circ} \mathrm{C}(50$ $\mathrm{sec}), 48^{\circ} \mathrm{C}(50 \mathrm{sec}), 72^{\circ} \mathrm{C}(50 \mathrm{sec})$ and a final extension at $72^{\circ} \mathrm{C}(5 \mathrm{~min})$. The sequencing was carried out at the facilities of the Inter-Institution Center of Group Use (Genom) (Engelhardt Institute of Molecular Biology of the Russian Academy of Sciences, Moscow) using the ABI PRISM ${ }^{\circledR}$ BigDye $^{\mathrm{TM}}$ Terminator v. 3.1 reagents kit. Reaction products were analyzed using an automatic sequencer ABI PRISM ${ }^{\circledR} 3730$ (Applied Biosystems).

We obtained new COI sequences from 12 specimens (Table 1). The resulting sequences were checked manually using a sequence alignment editor BioEdit v. 7.2.5 [Hall, 1999].

\section{Results}

Here we present the first records of four species of Lepidoptera for the Novaya Zemlya Archipelago with a supplement of the DNA barcoding data. In summary, 34 Lepidoptera species are recorded from Novaya Zemlya [Kullberg et al., 2018; this study].

\section{Crambidae}

Udea cf. cacuminicola Munroe, 1966

Fig. 1.

MATERIAL EXAMINED. Russia, Novaya Zemlya, Yuznhy Island, near the Bezymyannaya Bay, meadow-like association with Artemisia tilesii and Salix lanata, $72^{\circ} 50^{\prime} 42^{\prime \prime} \mathrm{N}, 53^{\circ} 44^{\prime} 21^{\prime \prime} \mathrm{E}, 19$ 26.XII.2017, Spitsyn leg. - 2 ex.

DNA BARCODING. A large number of species of Udea itysalis sp. group refers to lineages that have a genetic distance of less than $2 \%$ for COI, while the part of taxa is paraphyletic. It is likely that most of the currently accepted nominal taxa would represent synonyms. The specimens from Novaya Zemlya belong to $U$. cacuminicola Munroe 1966 having a rather shallow genetic divergence from other taxa in the species group. The closest sequences from Canada (Yukon) and the USA (Colorado) differ by $0.22-0.89 \%$, the sequence of "Udea costalis" (incorrect identification) from Russia (Primorsky Krai) differs by $0.45 \%$. From Udea itysalis on Kolguev Island (Nenets Autonomous District, Russia), it differs by $1.57 \%$.

\section{Geometridae}

Eupithecia gelidata Möschler, 1860

Fig. 2.

MATERIAL EXAMINED. Russia, Novaya Zemlya, Yuznhy Island, near the Bezymyannaya Bay, 72 $49^{\prime} 09^{\prime \prime} \mathrm{N}, 53^{\circ} 47^{\prime} 33^{\prime \prime} \mathrm{E}$, 21.XII.2017, Spitsyn leg. - 1 ex.

DNA BARCODING. We sequenced a specimen from Novaya Zemlya having a widespread haplotype that is known from Greenland to Norway and Italy.

\section{Rheumaptera subhastata (Nolcken, 1870)}

Fig. 3.

MATERIAL EXAMINED. Russia, Novaya Zemlya, Yuznhy Island, near the Bezymyannaya Bay, $72^{\circ} 49^{\prime} 09^{\prime \prime} \mathrm{N}, 53^{\circ} 47^{\prime} 33^{\prime \prime} \mathrm{E}$, 21.XII.2017, Spitsyn leg. - 1 ex.

DNA BARCODING. A sequence from Novaya Zemlya differs by one substitution from the COI haplotype common in Canada and by 2-3 substitutions from the series of the nearest haplotypes from Norway, Finland, Sweden, Austria, Germany, Canada, and the USA.

\section{Entephria byssata (Aurivillius, 1891)}

Fig. 4.

MATERIAL EXAMINED. Russia, Novaya Zemlya, Yuznhy Island, near the Bezymyannaya Bay, meadow-like association with Artemisia tilesii and Salix lanata, 72 $50^{\prime} 42^{\prime \prime} \mathrm{N}, 5^{\circ} 44^{\prime} 21^{\prime \prime} \mathrm{E}, 19$ 26.XII.2017, Spitsyn leg. - 6 ex; tundra with Astragalus alpinus, $72^{\circ} 51^{\prime} 10^{\prime \prime} \mathrm{N}, 5^{\circ} 42^{\prime} 48^{\prime \prime} \mathrm{E}, 19-26 . X I I .2017$, Spitsyn leg. - 6 ex; tundra with Hedysarum arcticum, 72 $52^{\prime} 24^{\prime \prime} \mathrm{N}, 53^{\circ} 38^{\prime} 48^{\prime \prime} \mathrm{E}, 19$ 21.XII.2017, Spitsyn leg. — 15 ex; tundra with Astragalus alpinus, $72^{\circ} 48^{\prime} 43^{\prime \prime}$ N, 5350'28"E, 23.XII.2017, Spitsyn leg. - 3 ex; tundra with Hedysarum arcticum, 72॰52'41 "N, 53³7'49"E, 23.XII.2017, Spitsyn leg. -7 ex; associations with Astragalus alpinus on the

Table 1. List of new COI sequences for moths obtained under this study. Таблица 1. Список новых последовательностей COI, полученных в ходе настоящего исследования.

\begin{tabular}{|l|c|c|c|}
\hline \multicolumn{1}{|c|}{ Species } & $\begin{array}{c}\text { NCBI's GenBank } \\
\text { acc. no. }\end{array}$ & Voucher no. & Specimen locality \\
\hline Udea cf. cacuminicola & MN700905 & Sph 705 & Russia: Novaya Zemlya \\
\hline Udea cf. cacuminicola & MN700906 & Sph 706 & Russia: Novaya Zemlya \\
\hline Eupithecia gelidata & MN700907 & Sph 707 & Russia: Novaya Zemlya \\
\hline Rheumaptera subhastata & MN700908 & Sph 708 & Russia: Novaya Zemlya \\
\hline Entephria byssata & MN700909 & Sph 709 & Russia: Novaya Zemlya \\
\hline E. byssata & MN700910 & Sph 710 & Russia: Novaya Zemlya \\
\hline E. byssata & MN700911 & Sph 711 & Russia: Novaya Zemlya \\
\hline E. byssata & MN700912 & Sph 712 & Russia: Novaya Zemlya \\
\hline E. byssata & MN700913 & Sph 713 & Russia: Novaya Zemlya \\
\hline E. byssata & MN700914 & Sph 714 & Russia: Novaya Zemlya \\
\hline E. byssata & MN700915 & Sph 715 & Russia: Novaya Zemlya \\
\hline E. byssata & MN700916 & Sph 716 & Russia: Novaya Zemlya \\
\hline
\end{tabular}


canyon slope, $72^{\circ} 50^{\prime} 15^{\prime \prime} \mathrm{N}, 53^{\circ} 22^{\prime} 41^{\prime \prime} \mathrm{E}, 23 . \mathrm{XII} .2017$, Spitsyn leg. $-1 \mathrm{ex}$; tundra with Hedysarum arcticum, $72^{\circ} 48^{\prime} 36^{\prime \prime} \mathrm{N}, 53^{\circ} 50^{\prime} 24^{\prime \prime} \mathrm{E}$, 23.XII.2017, Spitsyn leg. - 1 ex.

DNA BARCODING. We identified three haplotypes of this species on Novaya Zemlya, two of which are found in Scandinavia.

REMARK. Previously, this species (as Entephria punctipes) was listed in the fauna of the Novaya Zemlya Archipelago based on an incorrectly identified specimen of Psychophora sabini [Sumakow, 1912], and it was subsequently excluded from the list of the Lepidoptera species of Novaya Zemlya [Kullberg et al., 2018]. Entephria punctipes is considered as the Nearctic taxon at the present time [Aarvik et al., 2017]. Here, we present the first record of Entephria byssata from Novaya Zemlya that was confirmed by morphological characters and DNA barcoding.

\section{Discussion}

We can conclude that the studied species of Lepidoptera immigrated to Novaya Zemlya after the Last Glacial Maximum. Most of the species share widespread haplotypes or singletons. Similar biogeographic patterns are common for a number of other Lepidoptera in the Northern Palearctic [Bolotov et al., 2015; Spitsyn et al., 2020]. Studies of other animal groups of the fauna of Novaya Zemlya revealed that a number of taxa have endemic haplotypes and divergent lineages from this archipelago [Potapov et al., 2018; Makhrov et al., 2019]. Novaya Zemlya was suggested as a putative refugium for these groups [Potapov et al., 2018; Makhrov et al., 2019]. However, other taxa are represented by widespread haplotypes, e.g. reindeer [Kvie et al., 2016] and moths [this study].

Acknowledgements. The authors send their sincere gratitude to Dr. Elena Churakova for her help in preparing the paper. This study was partially supported by the Ministry of Science and Higher Education of Russia (Project No. AAAAA17-117033010132-2) and by the Russian Foundation for Basic Research (Projects No. 19-34-50016 and No. 19-3490012).

Competing interests. The authors declare no competing interests.

\section{References}

Aarvik L., Bengtsson B.Å., Elven H., Ivinskis P., Jürivete U., Karsholt O., Mutanen M., Savenkov N. 2017. Nordic-Baltic Checklist of Lepidoptera // Norw. J. Entomol. Suppl.3. P.1-236.

Bolotov I.N., Tatarinov A.G., Filippov B.Y., Gofarov M.Y., Kondakov A.V., Kulakova O.I., Potapov G.S., Zubryi N.A., Spitsyn V.M. 2015. The distribution and biology of Pararctia subnebulosa (Dyar, 1899) (Lepidoptera: Erebidae: Arctiinae), the largest tiger moth species in the High Arctic // Polar Biol. Vol.38. P.905-911. doi: 10.1007/s00300-014-1643-2

Folmer O., Black M., Hoeh W., Lutz R., Vrijenhoek R. 1994. DNA primers for amplification of mitochondrial cytochrome $\mathrm{c}$ oxidase subunit I from diverse metazoan invertebrates // Mol. Marine Biol. Biotechnol. Vol.3. P.294-299.

Hajibabaei M., Janzen D.H., Burns J.M., Hallwachs W., Hebert P.D. 2006. DNA barcodes distinguish species of tropical Lepidoptera // Proc. Natl. Acad. Sci. USA. Vol.103. No.4. P.968-971.

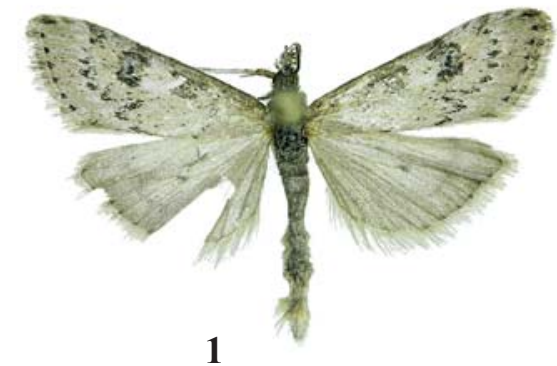

1

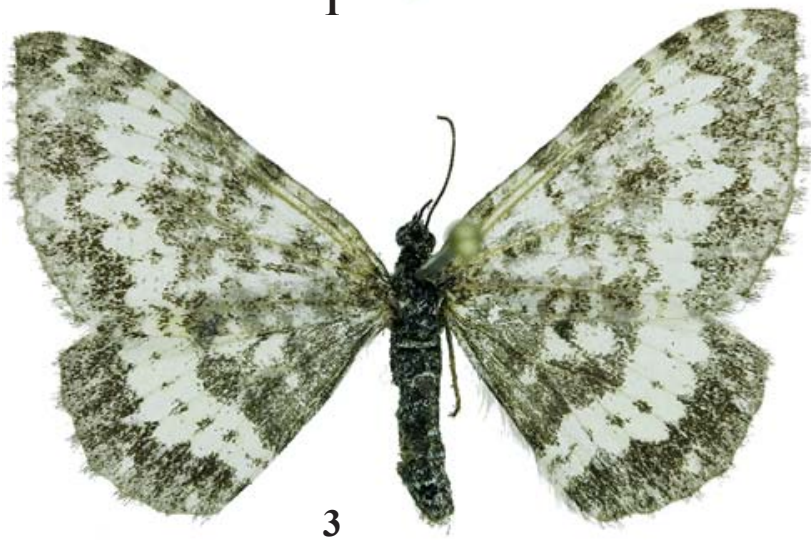

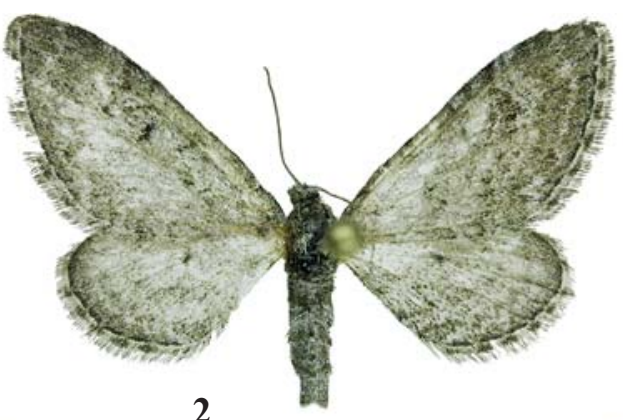

2

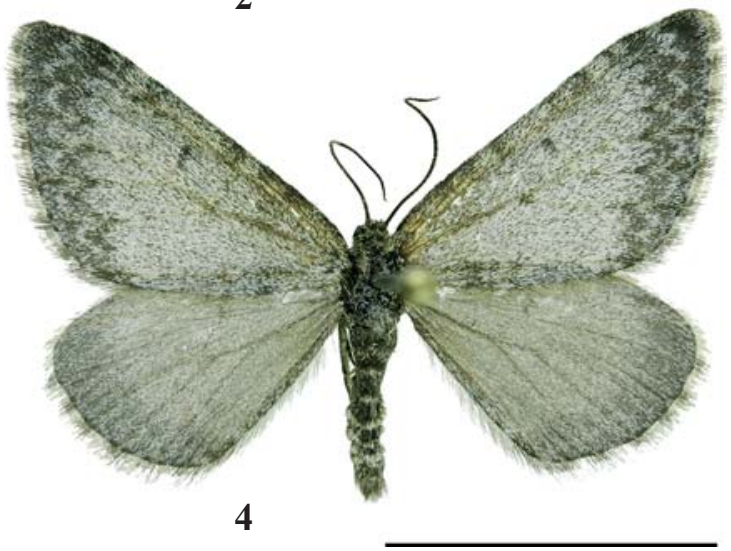

Figs 1-4. Moth species from Novaya Zemlya: 1 - Udea cf. cacuminicola Munroe, 1966; 2 - Eupithecia gelidata Möschler, $1860 ; 3$ Rheumaptera subhastata (Nolcken, 1870); 4 - Entephria byssata (Aurivillius, 1891). Scale bar = 10 mm. (Photos: Vitaly M. Spitsyn).

Рис. 1-4. Чешуекрылые архипелага Новая Земля: 1 - Udea cf. cacuminicola Munroe, 1966; 2 - Eupithecia gelidata Möschler, 1860; 3 - Rheumaptera subhastata (Nolcken, 1870); 4 - Entephria byssata (Aurivillius, 1891). Масштабная линейка = 10 мм. (Фото: B.M. Спицын). 
Hall T.A. 1999. BioEdit: a user-friendly biological sequence alignment editor and analysis. Department of Microbiology, North Carolina State University.

Jacobson G.G. 1898. [Zoological investigation on Novaya Zemlya in 1896. The insects of Novaya Zemlya] // Mémoires de l'Académie des sciences de St.-Pétersbourg. Classe des sciences physiques et mathématiques. VIIIe série. Vol.8. P.171-244 [in Russian].

Karsholt O., Nieukerken E.J. van. 2013. Fauna Europaea: Lepidoptera, moths. Fauna Europaea version 2017.06, https://faunaeu.org. Accessed 4 April 2018

Kullberg J., Filippov B.Y., Spitsyn V.M., Zubrij N.A., Kozlov M.V. 2018. Moths and butterflies (Insecta: Lepidoptera) of the Russian Arctic islands in the Barents Sea // Polar Biol. P.1-12. doi:10.1007/s00300-018-2425-z

Kullberg J., Filippov B.Y., Zubrij N.A., Kozlov M.V. 2013. Faunistic notes on Lepidoptera collected from arctic tundra in European Russia // Nota lepid. Vol.36. No.2. P.127-136.

Kvie K.S., Heggenes J., Anderson D.G., Kholodova M.V., Sipko T., Mizin I., Røed K.H. 2016. Colonizing the High Arctic: Mitochondrial DNA Reveals Common Origin of Eurasian Archipelagic Reindeer (Rangifer tarandus) // PLoS ONE. Vol.11. No.11. P.1-15. doi:10.1371/journal.pone.0165237

Makhrov A.A., Bolotov I.N., Spitsyn V.M., Gofarov M.Yu., Artamonova V.S. 2019. Resident and Anadromous Forms of Arctic Charr (Salvelinus alpinus) from North-East Europe: An Example of High Ecological Variability without Speciation // Dok1.
Biochem. Biophys. Vol.485. P.119-122.

Potapov G.S., Kondakov A.V., Spitsyn V.M., Filippov B.Yu., Kolosova Yu.S., Zubrii N.A., Bolotov I.N. 2018. An integrative taxonomic approach confirms the valid status of Bombus glacial$i s$, an endemic bumblebee species of the High Arctic // Polar Biol. Vol.41. No.4. P.629-642. doi:10.1007/s00300-017-2224-y

Rebel H. 1923. Lepidoptera von Novaja Semlja // Report of the Scientific Results of the Norwegian Expedition to Novaya Zemlya. No.7. P.1-15.

Sambrook J., Fritsch E.F., Maniatis T. 1989. Molecular Cloning: A Laboratory Manual, (2nd ed.). (pp. 10.51-10.67). Cold Spring Harbor: Cold Spring Harbor Laboratory Press.

Schauff M.E. (ed.). 2001. Collecting and preserving insects and mites: techniques and tools. Systematic Entomology Laboratory, National Museum of Natural History, USDA, Washington, DC, $68 \mathrm{pp}$

Spitsyn V.M., Berezin M.V., Kondakov A.V., Khruleva O.A., Tomilova A.A., Bolotov I.N. 2020. [Assessment of endemism level of Papilionoidea from Wrangel Island] // Arkticheskie issledovaniya: ot ekstensivnogo osvoeniya k kompleksnomu razvitiyu. Materialy II mezhdunarodnoi nauchno-prakticheskoi konferentsii. Arkhangelsk. P.442-444 [in Russian].

Sumakow G.G. 1912. [Beiträge zur Fauna der Insecten von Nowaja Semlja] // Sitzungsberichte der Naturforscer-Gesellschaft bei der Universität Jurjew (Dorpat). Vol.21. P.98-102 [in Russian]. 